\title{
ANALISA STRATEGI PEMBELIAN UNTUK MENDUKUNG KINERJA PENJUALAN PT INDO TEKNIK SISTEM
}

\author{
Ahmad Nurhadi ${ }^{1)}$ \\ 1)dosen universitas pamulang, email : mhadi1972@gmail.com
}

ARTICLES

INFORMATION

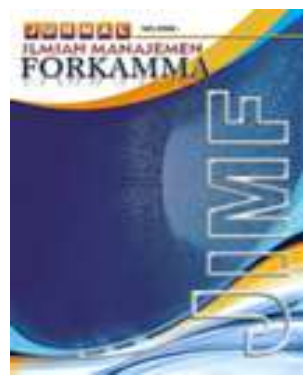

JURNAL ILMIAH MANAJEMEN FORKAMMA

\author{
Vol.1, No.2, Februari 2018 \\ Halaman : $33-49$ \\ (c) LPPM \& FORKAMMA
}

Prodi Magister Manajemen

UNVERSITAS PAMULANG

ISSN (online) : 2599-171X

ISSN (print) : :2598-9545

\section{Keyword:}

Strategi Pembelian, Kinerja

Penjualan, PT Indo Teknik

Sistem

JEL. classification :

C33, G20, G23, N65

\section{Contact Author : \\ PRODI \\ MAGISTER MANAJEMEN \& FORKAMMA UNPAM \\ JL.Surya Kencana No.1 Pamulang \\ Tangerang Selatan - Banten \\ Telp. (021) 7412566, Fax (021) 7412491 \\ Email : \\ jurnalforkamma.unpam@gmail.com}

Penelitian ini bertujuan untuk mengetahui strategi pembelian apa yang dapat dilakukan pada PT Indo Teknik Sistem terhadap strategi pembelian sudah dijalankan dengan mempertimbangkan faktor-faktor Internal dan faktor-faktor Eksternal pada lingkungan Perusahaan, dan untuk meningkatkan daya saing dalam pembelian produk pada lingkungan perusahaan Minyak dan Gas di Indonesia, serta perusahaan yang berkaitan sehingga meningkatkan kinerja penjualan.Metode penelitian yang digunakan adalah model penelitian deskriptif, dengan menggunakan analisa terhadap faktor internal, eksternal dan analisa melalui analisa IFE \& EFE dan analisa SWOT. Kondisi Penjualan PT Indo Tehnik Sistem berdasar analisis IFE \& EFE dalam posisi bertahan dan menjaga. Strategi yang harus dijalankan untuk meningkatkan kontribusi terhadap kenaikan kinerja penjualan adalah menerapkan strategi pembelian yang tepat dengan memberikan produk yang bersaing disaat permintaan mengalami kenaikan, dengan memberikan kepastian tentang jaminan produk dengan mempertimbangkan untuk mencari sumber pengadaan lebih dari satu tempat, dengan mempertimbangkan karakter dan kriteria dengan meminimalkan keterlambatan dan ketidakpastian pengiriman produk bagi pelanggan, sehingga tercipta kepuasan pelanggan dan bisa mendukung jangkauan pasar yang dimiliki oleh pesaing kita, yang akhirnya dapat meningkatkan kinerja penjualan.

This study aims to find out what purchasing strategy that can be done at PT Indo Teknik Sistem towards purchasing strategy has been executed by considering Internal factors and External factors in Company environment, and to improve competitiveness in purchasing product in environment of company of Oil and Gas in Indonesia,

The research method used is descriptive research model, using analysis of internal factors, external and analysis through IFE \& EFE analysis and SWOT analysis. Sales Condition PT Indo Tehnik System based on IFE \& EFE analysis in a defensive and maintain position. The strategy that must be pursued to increase the contribution to the increase in sales performance is to apply the appropriate purchasing strategy by delivering competing products as demand increases, providing assurance of product warranty by considering the procurement source of more than one place, taking into account the characters and criteria minimize delays and product delivery uncertainty for customers, resulting in customer satisfaction and can support the market reach of our competitors, which ultimately can improve sales performance 


\section{A. Pendahuluan}

PT. Indo Teknik Sistem merupakan bagian dari suatu perusahaan dalam kategori sedang berkembang, dengan bidang perdagangan umum dengan spesifik untuk pengadaan yang menunjang kegiatan perusahaan yang membutuhkan peralatan yang berhubungan dengan kegiatan perusahaan Minyak dan Gas Bumi dan Perusahaan yang sejenis.

Dengan berkembangnya waktu dalam menjalankan usaha tersebut ada beberapa kendala dalam mengoptimalkan keuntungan yang harus didapat, dimana sampai dengan saat ini dalam mengelola pengeluaran yang berhubungan dengan pendukung untuk menghasilkan keuntungan yang maksimal yiatu dengan sistem pembelian yang dilakukan dengan sistem pembayaran tunai. Secara aliran kas perusahaan tentu hal ini akan membebani dalam operasional perusahaan yang sedang berkembang dalam menghadapi daya saing untuk mendapatkan keuntungan yang maksimal. Pembelian yang dilakukan saat ini adalah pembelian tunai dengan berdasarkan dari Purchase Order ( PO ) dari pelanggan ( Customer ) yang membutuhkan peralatan atau material yang dibutuhkan. Setelah adanya PO tersebut maka, secara paralel perusahaan memesan kepada perusahaan yang memiliki kualifikasi dari yang dibutuhkan. Pemesanan yang dilakukan bisa dari luar negeri misalnya dari Negara Belanda, Perancis \& German. Pemesanan dilakukan sesuai dari permintaan dari Perusahaan yang membutuhkan dan ini harus dipastikan bahwa barang yang dipesan kepada penyedia barang tersebut harus sesuai dengan kualifikasi dari pemesan. Kualifikasi yang harus dan menjadi acuan adalah dari segi Material yang digunakan, Ukuran, Fungsi dan Kegunaan dari material yang dipesan.

Untuk saat ini hal yang terasa sangat diperhatikan adalah dengan komposisi bagian pembelian yang belum sepenuhnya bisa berjalan sesuai dengan yang diharapkan, dikarenakan sumber tempat pembelian hanya ada luar negeri dan hal ini tentunya menambah biaya yang dikeluarkan, dan perlu suatu antisipasi jika ada kendala dalam pemesanan yang tidak sesuai dan adanya pengiriman barang yang tidak sesuai dengan rencana dan schedule yang ada.

Produk yang telah dibeli sampai saat ini adalah pembelian tentang produk yang berhubungan dengan Perusahaan Minyak dan Gas, di wilayah Timur Indonesia, dengan berkontrobusi untuk pengembangan dalam pengelolaan Minyak dan Gas, yang manfaatnya tentu untuk kebutuhan rakyat membutuhkannya.

Jenis Produk yang dibeli untuk Perusahaan Minyak dan Gas tersebut kita ambil dari mitra kerja kami, yang sudah terlebih dahulu kita seleksi tentang sejarah dan kualitas produk yang diberikan yang berasal dari Negara Belanda, Perancis, Singapore, Australia dan German. Mekanisme untuk pembayaran selama ini adalah dengan sistem pembelian dengan cara tunai untuk saat pertama kali melakukan transaksi, dalam tahun pertama. Jika pemesanan dilakukan kembali dengan tempat yang sama maka kami akan mengajukan keringanan dalam pembayaran dengan cara lebih fleksibel dengan mengajukan pembayaran dengan DP ( Down Payment) dan sisanya akan dibayarkan sebelum barang dikirim..

Setelah dilakukan pembukaan PO dari manajemen kepada pihak principal maka langkah selanjutnya adalah mengirim bukti tertulis permintaan produk tersebut via email sebagai bukti tertulis dan sebagai dasar dalam mengadakan kerjasama yang saling menguntungkan.

Hal yang sangat diperhatikan adalah mengenai pembayaran yang dilakukan setelah PO diterbitkan, yaitu harus berdasarkan perjanjian, untuk permulaan biasanya harus membayar terlebih dahulu ( Prepaid Pay) artinya pembayaran seluruhnya didepan, hal ini sempat membuat khawatir tetapi tetap yakin karena adanya 
komunikasi yang sudah terjalin serta dilengkapi dengan dokumen legal yang ada. Dan selanjutnya seiring berjalannya waktu akan diberikan kepercayaan dengan DP 50\% dan sisanya adalah sebelum barang dikirim ketempat tujuan, dan hal ini berjalan sampai sekarang. Tidak menutup kemungkinan bahwa dikemudian hari akan mendapatkan syarat yang lebih baik dengan diberikan jaminan kredit 2 ( dua ) minggu setelah barang sampai atau idealnya 1 ( satu ) bulan setelah barang terkirim, kemudian baru dilakukan pembayaran.

Sebagai perusahaan penyedia barang, sistem penjualan yang diterapkan adalah dengan melakukan penawaran kepada pihak yang membutuhkan kepada Perusahaan lain yang ingin dibantu agar menjadi lebih mudah dalam menjalankan operasionalnya. Pembelian yang dilaksanakan selama ini berdasarkan pesanan dari pihak perusahaan yang membutuhkan, serta adanya hubungan yang baik dari pemilik dengan kompetensi bidang yang dimiliki, sehingga memudahkan dalam pencarian produk yang diiinginkan dan sumber pembelian yang masih mengandalkan dari pihak luar negeri menjadi tantangan yang harus disikapi agar bisa diestimasi kerugian yang timbul dari ketidakpastian pembelian dimana pasti berhubungan dengan fluktuasi nilai rupiah terhadap mata uang asing dalam melaksanakan transaksi.

$\mathrm{Hal}$ ini mengharuskan perusahaan harus bisa berkompetisi dengan perusahaan pesaing untuk bisa mendapatkan sumber pembelian produk agar sesuai dengan yang diinginkan oleh pembeli, dan harus mempunyai daya saing dengan perusahaan yang lain yaitu dengan meningkatkan mutu barang yang diberikan, ketepatan waktu, serta dengan harga yang bersaing.

Dengan permasalahan yang ada dalam perusahaan ini, maka penulis melakukan penelitian ini dengan menggunakan analisa Matriks Space dan analisa SWOT yang bertujuan untuk bisa mengetahui perkembangan perusahaan, mengetahui kekuatan, kelemahan, kesempatan dan tantangan yang harus dilaksanakan oleh perusahaan agar bisa menentukan strategi pembelian yang tepat dan mempunyai daya saing sehingga mendapatkan sumber pembelian, dan dapat memberikan kontribusi kepada perusahaan dalam mendapatkan kinerja penjualan sehingga menghasilkan keuntungan yang maksimal.

Sumber pembelian menjadi hal yang mendasar dalam mengukur kinerja penjualan, dimana suatu perusahaan dalam hal memenuhi pengadaan ini seringkali hanya mengandalkan sumber dari luar negeri dikarenakan selama ini sumber dari dalam negeri belum dapat memenuhi, dari yang diharpakan, kaena keterbatasan sumber daya alam dan sumber daya manusia terutama yang berhubungan dengan penguasaan teknologi yang berhubungan dengan penggunaan suatu produk yang berkaitan erat dengan kebutuhan yang dibutuhkan perusahaan Minyak dan Gas, dimana mempunyai kekhususan dalam hal spec, kualitas dan fungsinya.

Selanjutnya dalam mendapatkan sumber pembelian yang ada selama ini yang masih mengandalkan dari sumber luar negeri menjadi hal yang mendasari sebagai peneliti untuk bisa memberikan kontribusi bahwa sumber pembelian dari pihak luar negeri bisa di rencanakan dan lebih dimaksimalkan agar tidak mengganggu kinerja penjualan perusahaan.

Perusahaan selalu berharap untuk selalu berkembang dan bisa tetap eksis dibidangnya dengan selalu bisa mendapatkan sumber pembelian dalam rangka untuk meningkatkan kinerja penjualan sehingga menghasilkan keuntungan yang maksimal. Langkah - langkah yang dilakukan adalah dengan selalu mengutamakan sumber pembelian yang jelas dan dengan sistem pembayaran yang sesuai dengan likuiditas perusahaan, dan tidak mengganggu aliran kas perusahaan.

Persaingan dalam Perusahaan yang menyediakan barang dan jasa semakin lama semakin banyak yang bermunculan, hal ini tidak menutup kemungkinan akan menambah persaingan dalam mendapatkan sumber pengadaan dan pembelian produk dan jasa yang akan dijual kepada pelanggan. 
Untuk mengatasi hal ini maka diperlukan suatu cara dan strategi untuk bisa bertahan dan menambah daya saing bagi perusahaan supaya tetap eksis dalam persaingan, hal ini diperlukan analisa yang bisa membantu memecahkan masalah yang harus dihadapi oleh perusahaan.

PT Indo Tehnik Sistem dalam hal ini merupakan salah satu Perusahaan yang bergerak dalam bisnis pengadaan barang dan jasa khususnya menjadi mitra dari Perusahaan Minyak dan Gas di Indonesia, dalam penyediaan barang dan jasa yang dibutuhkan, dimana perusahaan harus memahami kekuatan dan kelemahan yang dimiliki untuk menghadapi persaingan dalam bisnis yang terjadi, dikarenakan sangat bermanfaat untuk membantu dan memaahami, serta memanfaatkan setiap peluang yang ada untuk menghindari dari ancaman.

Perusahaan harus selalu melakukan terobosan dalam mendapatkan sumber dan peluang dalam pembelian dengan menggunakan strategi pembelian, dengan tujuan utamanya adalah untuk mencari sumber tepat untuk mendapatkan produk yang berkualitas dan mempunyai harga yang bersaing agar dapat berkompetisi secara sehat terhadap perusahaan pesaing dan mencari peluang untuk bisa mendapatkan sumber produk yang secara tekhnis mempunyai fungsi dan kegunaan yang sama dengan kandungan tehnologi yang lebih baik. Kunci sukses dalam sebuah perusahaan dapat bersaing tergantung dari penyesuaian secara dinamis terhadap lingkungan sekitar yang relative kompleks dan tidak stabil.

\section{Fokus Masalah}

1. Menganalisa kinerja penjualan yang terjadi pada PT Indo Tehnik Sistem .

2. Penelitian kinerja penjualan ini khusus dilakukan PT Indo Tehnik Sistem yang merupakan single case atau single unit analysis

3. Penelitian ini focus mengkaji dan menganalisa guna menetapkan strategi yang lebih tepat bagi strategi penmbelian dalam penyediaan produk unggulan.

\section{Perumusan Masalah}

1. Bagaimana kondisi Strategi pembelian dalam mendukung kinerja Penjualan yang dilakukan PT Indo Tehnik Sistem saat ini.

2. Bagaimana Strategi Pembelian yang lebih baik untuk meningkatkan kinerja Penjualan PT Indo Tehnik Sistem.

\section{Tujuan Penelitian}

Berdasarkan perumusan masalah diatas, maka ditetapkan tujuan penelitian sebagai berikut :

1. Untuk mengetahui bagaimana kinerja pembelian PT Indo Tehnik Sistem saat ini.

2. Untuk mengetahui bagaimana strategi Pembelian yang dilakukan PT Indo Tehnik Sistem yang lebih baik.

\section{Manfaat Penelitian}

Adapun manfaat dalam penelitian ini adalah sebagai berikut:

\section{Untuk Keilmuan}

Hasil penelitian ini diharapkan akan melengkapi bahan penelitian selanjutnya dalam rangka menambah khasanah akademik sehingga berguna untuk pengembangan ilmu dan agar bisa dipraktekkan secara nyata tentang strategi pembelian dalam hal mendapatkan sumbernya untuk sebuah perusahaan yang sedang berkembang dalam penyediaan barang dan Jasa.

\section{Untuk Institusi}

Hasil penelitian ini diharapkan dapat memberikan masukan kepada pihak manajemen perusahaan tentang pentingnya penerapan strategi pembelian produk, 
sehingga memberikan kontribusi terhadap keuntungan yang maksimal bagi perusahaan, dengan pencapaian target yang telah ditetapkan oleh manajemen.

\section{B. Landasan Teori}

\section{Manajemen Strategi}

Manajemen strategis adalah proses untuk membantu organisasi dalam mengidentifikasi apa yang ingin mereka capai, dan bagaimana seharusnya mereka mencapai hasil yang bernilai. Peranan manajemen semakin banyak diakui pada masa masa sekarang dan masa sebelumnya. Dalam perekonomian global saat ini dimana pergerakan barang dan jasa secara bebas lintas Negara, perusahaan harus bisa kompetitif dengan tantangan yang ada. Beberapa perusahaan yang telah meningkatkan tingkat kompetisinya ini menawarkan produk kepada konsumen dengan nilai yang tinggi, dan hal ini sering menghasilkan laba diatas rata-rata ( Muchael A. Hitt \& R. Duane Ireland \& Robert E. Hoslisson ( 1997, XV ). Dengan menggunakan menajemen strategis, perusahaan akhirnya dapat memahami kekuatan bersaing dan mengembangkan keunggulan kompetitif berkelanjutan secara sistematis dan konsisten.

Memiliki daya saing strategi dan laba diatas rata-rata adalah tantangan untuk perusahaan sebesar AT \& T kecil seperti halnya sebuah toko. Model berbasis sumber daya. Apabila kriteria-kriteria tersebut dipenuhi, sumber daya dan kemampuan menjadi kompetensi inti dan dapat berlaku sebagai dasar keunggulan bersaing perusahaan, daya saing strategis, dan kemampuannya untuk mendapatkan laba diatas rata-rata.

Kerja keras, analisis yang teliti dan akal sehat merupakan persyaratan keberhasilan seorang ahli strategi. Selain kerja keras, analisis yang menyeluruh dan akal sehat, ahli strategi yang efektif harus dapat berpikir dengan jernih dan melontarkan banyak pertanyaan. Efektifitas strategi mereka akan meningkat apabila mereka menemukan cara bagi yang lain untuk berpikir dan bertanya mengenai apa yang dilakukan perusahaan dan mengapa. Tetapi khususnya, manajer puncak ditantang untuk bisa berpikir serius dalam mendalami tujuan organisasi yang mereka pimpin atau fungsi yang mereka lakukan, mengenai strategi, taktik, tekhnologi, sistem dan orang-orang yang diperlukan untuk mencapai tujuan tersebut.

\section{Strategi Pembelian}

Suatu proses pengadan barang tentu memiliki tujuan tersendiri, tujuan tersebut akan dimanfaatkan dalam jangka pendek, jangka menengah maupun jangka panjang. Berikut beberapa manfaat dari pengadaan barang:

\section{- Kelangsungan usaha perusahaan}

Perusahaan industri atau pabrik sangat bergantung kepada proses produksi, bila tidak ada pengadaan bahan baku yang terjadi dari waktu ke waktu tentu proses produksi untuk mengahsilkan barang tidak akan terwujud. Ketika kebutuhan pasar akan barang yang dibutuhkan konsumen tidak mampu dipehuni perusahaan akibat tidak ada proses pengadaan barang maka konsumen akan berpindah pada barang serupa namun dari produsen lainnya.Kelangsungan usaha perusahaan sangat bergantung dari proses produksi dan pengadaan barang yang dilakukan. Karena itu proses pengadaan barang baik dalam jangka pendek, jangka panjang, jangka menengah sangat penting untuk kelangsungan usaha perusahaan bersangkautan. Bila kelangsungan usaha perusahaan tetap berjalan maka keberadaan perusahaan tidak akan tergantikan produsen lainnya. 
- Memaksimalkan laba

Dimanapun suatu usaha dilakukan untuk menghasilkan laba yang besar, secara tidak langsung proses pengadaan barang bertujuan untuk mendapatkan keuntungan perusahana bersangkutan. Bila pengadaan barang berjalan lancar sehingga akan memudahkan proses produksi maka penjualan kepada konsumen bisa dilakukan tepat waktu. Kapan konsumen membutuhkan barang akan dipenuhi oleh perusahaan tanpa harus menunggu barang di pasaran habis dan timbul kekosongan barang dalam waktu yang lama. Semakin cepat perusahaan melakukan umpan balik atas kebutuhan konsumen dan perusahaan mampu memenuhi kebutuhan tersebut dalam waktu cepat maka konsumen akan tetap menggunakan produk yang sama. Pengadaan barang yang baik dan sesuai kebutuhan konsumen di pasaran akan memaksimalkan laba perusahaan. Namun ketika bahan baku yang digunakan untuk produksi tidak tersedia di gudang, ini akan membuat proses produksi tertunda dan konsumen akan beralih pada produsen lainnya yang bisa memenuhi kebutuhan mereka dengan cepat.

- Meningkatkan kesejahteraan karyawan

Sebagian laba yang didapatkan perusahaan digunakan untuk kebutuhan karyawannya. Karena usaha yang dilakukan oleh perusahaan baik pada proses pengadaan barang, produksi maupun penjualan selalu melibatkan karyawan, hasil dari proses tersebut juga untuk kesejahteraan karyawan. Balas jasa yang diberikan perusahaan kepada karyawan adalah gaji dan beberapa tunjangan lainnya, ini bisa dipenuhi oleh perusahaan bila perusahaan tersebut memiliki pendapatan yang besar untuk memenuhi kebutuhan karyawannya. Pendapatan perusahaan bergantung pada penjualan produk, penjualan diawali dengan perencanaan produksi, perencanaan pengadaan barang dan prosesnya. Siklus ini saling berhubungan dan bila salah satu mengalami kendala maka akan berakibat juga pada komponen lainnya. Bila ingin proses produksi lancar maka pengadaan barang pun juga harus lancar.

\section{- Memenangkan pangsa pasar}

Bila proses produksi suatu perusahaan tidak berjalan dengan lancar, perusahaan pun tidak akan mampu untuk memenuhi kebutuhan konsumennya dipasaran. Bila salah satu produk ada yang kosong, produsen lain atua perusahaan lain akan masuk kedalam pasar bersangkutan untuk menggantikan kekosongan barang tersebut. Sekali perusahaan tidak mampu memenuhi kebutuhan konsumen maka pemenuhan kebutuhan berikutnya akan tergantikan oleh perusahaan lainnya sekalipun itu adalah barang yang sama. Bagi perusahaan untuk mencegah terjadinya pergeseran produk oleh produsen lain maka proses pengadaan barang ini memang perlu diperhatikan. Jangan sampai barang yang dibutuhkan untuk proses produksi tidak ada di gudang saat produksi akan dilaksanakan. Ketika perusahaan mampu menyediakan produk yang dibutuhkan konsumen dengan cepat dan tepat, dialah yang akan memenangkan pasar tersebut.

Bila kegiatan pengadaan barang dan jasa sejalan dengan strategi perusahaan maka perusahaan akan mendapatkan kemudaan dalam produksi barang yang akan dijual di pasaran. Ketika perusahaan sedang menjalankan strategi pengurangan biaya maka pengadaan harus disesuaikan dengan strategi yang sedang dijalankan oleh perusahaan. Dan yang menjadi kunci utama, sekalipun pabrik atau 
perusahaan menjalankan berbagai inovasi pada barang pengadaan tersebut jangan sampai kualitas dari output yang dihasilkan menurun. Sekalipun banyak dilakukan inovasi namun jangan sampai proses pengadaan barang yang dilakukan perusahaan mempengaruhi kualitas produk yang dihasilkan.

\section{Kerangka Pemikiran}

Perkembangan bisnis mengharuskan suatu Perusahaan, harus mempunyai strategi untuk menjalankan bisnisnya agar bisa terus bisa bertahan dan mempunyai daya saing dalam mempertahankan segmen pasar yang dimilikinya atau bahkan bisa mengembangkannya, dan bisa meningkatkan kinerja Perusahaan dengan adanya strategi dalam hal pembelian untuk meningkatkan kinerja penjualan.

PT Indo Tehnik Sistem merupakan salah satu penyedia barang dan jasa di lingkungan Perusahaan Minyak dan Gas yang berada didaerah Indonesia. Perkembangan Perusahaan yang bisa dan mampu untuk bisa bekerja sama dengan Perusahaan Minyak dan gas semakin banyak, dan semakin meningkat. Hal ini akan memacu kepada perusahaan untuk bisa bersaing dalam memasarkan produk yang dimiliki dengan keterbatasan pangsa pasar yang ada.

Sementara akses yang dimiliki dalam hal pembelian dirasakan belum maksimal atau optimal sehingga perlu dicari langkah terobosan agar bisa menerapkan strategi pembelian yang bisa meningkatkan kinerja penjualan.

Strategi yang dimiliki saat ini adalah dengan mengandalkan pembelian dari pihak luar yang mampu mengakomodir permintaan dari customer, dengan jaminan dan kualitas barang yang baik, walaupun disisi lain memerlukan biaya yang lebih untuk mendapatkannya.

Untuk mengetahui strategi pembelian yang dipergunakan, maka peneliti melakukan analisa yaitu dengan analisa Metode IFE \& EFE dengan tujuan mengetahui tingkat kinerja penjualan perusahaan dan tingkat pangsa pasar terhadap pembelian produk dan dengan analisa Metode SWOT dengan tujuan untuk mengukur strategi apa yang cocok dengan perusahaan. Dengan kedua analisa yang mendalam secara deskriptif tersebut maka diharapkan dapat menghasilkan dan menerapkan Strategi Pembelian yang lebih tepat.

Hasil dari rangkaian analisa secara deskriptif ini akan memberikan suatu rekomendasi alternatif kepada PT Indo Teknik Sistem agar kinerja penjualan bisa meningkat.

Dari uraian tersebut diatas maka dikembangkanlah kerangka pemikiran teoritis sebagaimana terlihat dalam Gambar B.1 Kerangka Pemikiran berikut ini: 
Belum Maksimalnya Kinerja Penjualan PT Indo Teknik Sistem

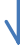

Akses Pembelian yang belum Optimal

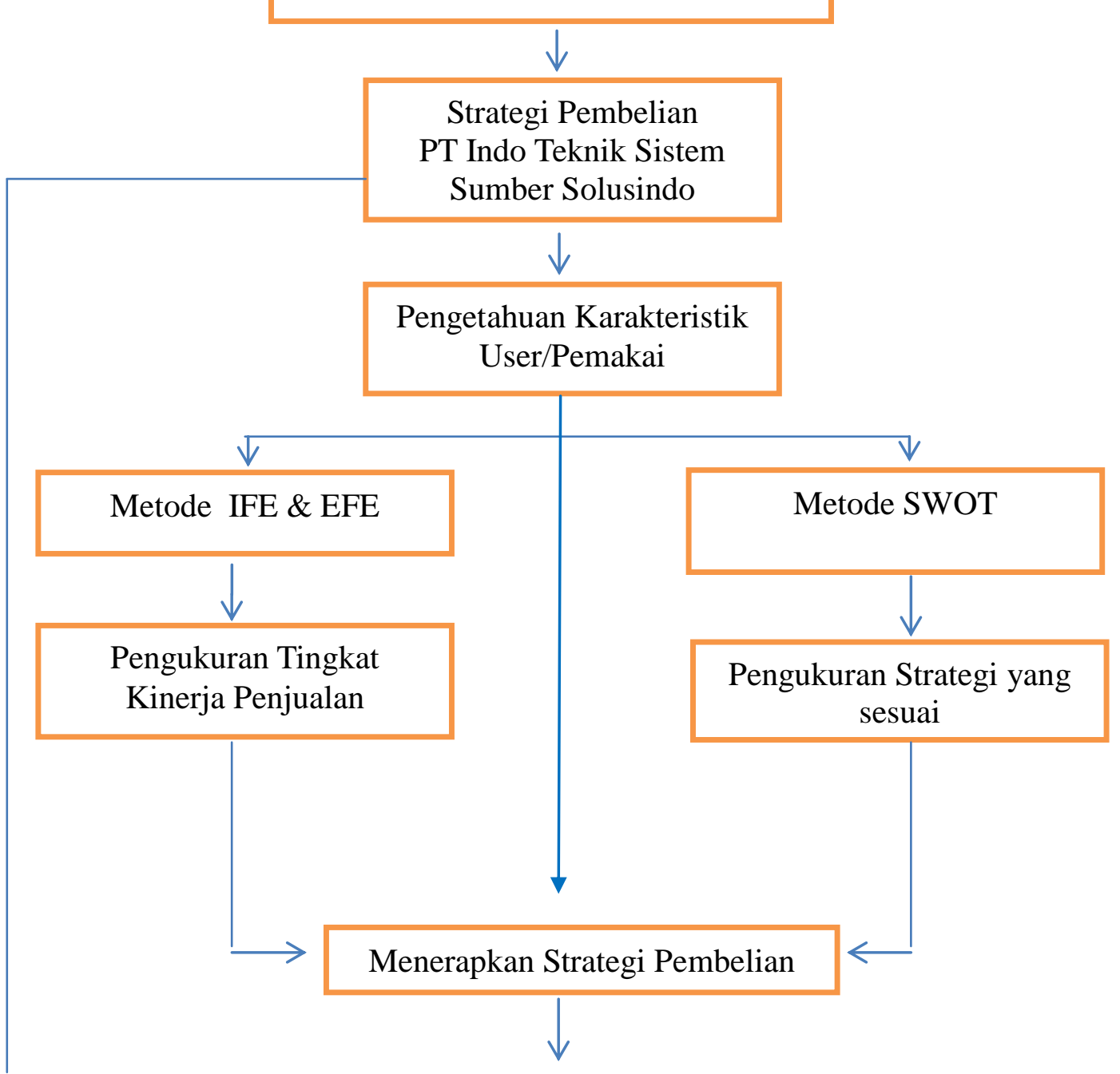

Rekomendasi Alternatif untuk PT Indo Tehnik Sistem

Proposisi : 1. Kinerja Penjualan PT Indo Tehnik Sistem saat ini belum Optimal

2. Kinerja Penjualan PT Indo Tehnik Sistem bisa dioptimalkan melalui perbaikan strategi Pembelian 


\section{Metode Penelitian \\ Desain Penelitian}

Desain penelitian merupakan bagian dari perencanaan penelitian yang menunjukkan usaha peneliti dalam melihat apakah penelitian yang direncanakan telah memiliki validitas internal dan validitas eksternal yang komprehensif.

Peneliti membuat desain penelitian dengan terlebih dahulu menitikberatkan kepada fokus yang akan diteliti, berikut masalah yang ada pada perusahaan PT Indo Teknik Sistem, permasalahan yang menjadi inti saat ini adalah strategi pembelian telah dilakukan dengan cara mencari sumber dari pengadaan barang yang dibutuhkan customer dari luar negeri, dengan cara pembayaran secara tunai sehingga likuiditas perusahaan harus selalu terjaga jika tidak ingin kinerja penjualan terganggu.. Kedua hal ini yang dipakai dalam memenuhi permintaan dari customer yang dilakukan oleh team pengadaan. Hal ini dibandingkan dengan teori atau kajian pustaka yang ada tentang strategi pembelian yang berkembang saat ini, apakah 2 cara yang dilakukan tersebut sudah sesuai atau ada hal yang perlu dikembangkan dan diperbaiki untuk mendapatkan hasil yang maksimal dalam mengukur kinerja Penjualan Perusahaan.

Kemudian dari hal tersebut dilakukan analisa data dengan memakai analisa Metode IFE \& EFE dan analisa Metode SWOT, dengan mempertimbangkan data dari informasi yang akurat dan terpercaya, sehingga menghasilkan analisa yang tepat, sehingga akan mendapatkan hasil atau kesimpulan yang dapat dijadikan rekomendasi tentang strategi pembelian yang cocok untuk perusahaan PT Indo Tehnik Sistem agar bisa menghasilkan kinerja penjualan yang optimal demi kelangsungan perusahaan.

\section{Tehnik Analisa Data}

Teknik analisa dalam penelitian kualitatif ini adalah dengan menggunakan data yang diperoleh dari berbagai sumber, dengan menggunakan teknik pengumpulan data yang bermacam-macam ( triangulasi ), dan dilakukan secara terus menerus sampai datanya jenuh. Dengan pengamatan yang terus menerus tersebut mengakibatkan variasi data.Proses analisa data kualitatif dibagi menjadi 3 bagian yaitu :

1. Analisa sebelum di lapangan

2. Analisa Data di Lapangan Model Miles dan Huberman
a. Data Reduction ( Reduksi Data )
b. Data Display (Penyajian Data)
c. Conclusion Drawing/Verification

3. Analisa Data selama di Lapangan model Spradley

- Analisa Domain

- Analisa Taksonomi

- Analisa Kompnensial

- Analisa Tema Budaya

4. Rancangan Analisis Data pada Pelaporan

- Analisis IFE \& EFE

- Analisis SWOT 


\section{E. Hasil Penelitian dan Pembahasan}

\section{Analisa IFE \& EFE, Matrik SWOT pada PT Indo Tehnik Sistem}

Analaisa IFE \& EFE adalah analisa tentang pengaruh Internal dan Eksternal Perusahaan yang diharapkan akan mampu untuk mengetahui kinerja Penjualan, untuk mengetahui pangsa pasar ( market share) dan untuk mengetahui strategi Pembelian yang dilakukan oleh PT. Indo Tehnik Sistem.

Analisa SWOT merupakan identifikasi dari berbagai faktor secara sistematis untuk merumuskan Strategi Perusahaan. Analisa ini didasarkan kepada hubungan atau interaksi antara unsur-unsur internal, yaitu kekuatan ( strength ) dan kelemahan ( weakness ), terhadap unsur-unsur eksternal yaitu peluang ( opportunity ) dan ancaman ( threat ).

\section{Evaluasi Analisa dengan menggunakan Matriks IFE \& EFE}

\begin{tabular}{|c|c|c|c|}
\hline \multicolumn{1}{|c|}{ Variabel Internal } & Bobot & Rating & BxR \\
\hline Kekuatan & & & 0,60 \\
\hline$-\quad$ Harga Produk & 0,15 & 4 & 0,60 \\
\hline$-\quad$ Kualitas Produk & 0,15 & 4 & 0,60 \\
\hline$-\quad$ Keberlangsungan Produk & 0,10 & 4 & 0,15 \\
\hline - Jaminan Produk & 0,05 & 3 & 0,45 \\
\hline Kelemahan & 0,15 & 3 & 0,10 \\
\hline$-\quad$ Produk Impor & 0,05 & 2 & 0,10 \\
\hline - Resiko Produk Pesanan & 0,05 & 2 & 0,05 \\
\hline - Belum adanya Persediaan & 0,05 & 1 & 0,10 \\
\hline - Pembayaran Harus Tunai & 0,10 & 1 & 0,05 \\
\hline - Pengiriman Tidak Selalu Lancar & 0,05 & 1 & 2.8 \\
\hline TOTAL & 1,00 & & \\
\hline
\end{tabular}

\begin{tabular}{|c|c|c|c|}
\hline \multicolumn{1}{|c|}{ Variabel Eksternal } & Bobot & Rating & BxR \\
\hline Peluang & & & \\
\hline$-\quad$ Kenaikan Permintaan & 0,20 & 4 & 0,80 \\
\hline - Segmen Pasar bisa Diperluas & 0,10 & 4 & 0,40 \\
\hline - Market Share bisa dinaikan & 0,10 & 4 & 0,40 \\
\hline - Market Growth bisa ditingkatkan & 0,10 & 3 & 0,30 \\
\hline
\end{tabular}




\begin{tabular}{|c|c|c|c|}
\hline Ancaman & & & \\
\hline- Adanya Perusahaan baru sejenis & 0,02 & 2 & 0,04 \\
\hline $\begin{array}{l}\text { Sumber Pengadaan yang lebih } \\
\text { banyak }\end{array}$ & 0,05 & 2 & 0,10 \\
\hline Kompetitor memiliki dana lebih & 0,05 & 1 & 0,05 \\
\hline $\begin{array}{l}\text { Pemain lama memiliki } \\
\text { Persediaan }\end{array}$ & 0,05 & 1 & 0,05 \\
\hline $\begin{array}{l}\text { Kompetitor memiliki jaringan } \\
\text { Pasar yang luas }\end{array}$ & 0,03 & 1 & 0,03 \\
\hline TOTAL & 1,00 & & 2.77 \\
\hline
\end{tabular}

\begin{tabular}{|c|c|c|c|c|c|}
\hline & & \multicolumn{4}{|c|}{ SKOR BOBOT TOTAL IFE } \\
\hline & & & KUAT & SEDANG & LEMAH \\
\hline & & & $3.0-4.0$ & $2.0-2.99$ & $1.0-1.99$ \\
\hline $\mathbf{S}$ & & 5 & 4 & 3 & 2 \\
\hline $\begin{array}{l}K \\
O \\
R \\
\text { B } \\
\text { O }\end{array}$ & $\begin{array}{l}\text { TINGGI } \\
3.0-4.0\end{array}$ & & 1 & II & III \\
\hline $\begin{array}{l}\text { B } \\
0 \\
\text { T } \\
\\
T \\
\text { O }\end{array}$ & $\begin{array}{l}\text { SEDANG } \\
2.0-2.99\end{array}$ & 3 & IV & $\begin{array}{c}(2,77: 2,8) \\
V\end{array}$ & VI \\
\hline $\begin{array}{l}\mathbf{T} \\
\mathbf{A} \\
\mathbf{L}\end{array}$ & $\begin{array}{l}\text { RENDAH } \\
1.0-1.99\end{array}$ & 2 & VII & VIII & IX \\
\hline & & 1 & & & \\
\hline & & & I, II \& IV = TUMBUH & MBANGUN & \\
\hline & & & III, V, VII = MENJAG & IEMPERTAHANKAN & \\
\hline & & & VI, VIII, IX = PANEN & TASI & \\
\hline
\end{tabular}

Berdasar pada tabel David dalam Matriks Internal \& Eksternal ( Tahun : 2002 , hal 26 ) kondisi penjualan PT Indo Tehnik Sistem berada pada posisi bertahan dan berjaga.

Kondisi saat ini jika dilihat dari data bahwa variabel kekuatan dan kelemahan mempunyai nilai 2.8 dimana variable kekuatan diangka 2.14 ditandai 
dengan adanya unsur harga, merk, kualitas produk, keberlangsungan produk dan jaminan produk sedangkan variable kelemahan diangka 0.4 ditandai dengan adanya unsur produk masih impor, resiko produk pesanan, belum adanya persediaan, pembayaran harus tunai, dan pengiriman belum lancar yang berarti bahwa untuk nilai kekuatan harus dipertahankan sedangkan untuk nilai kelemahan dicarikan jalan keluar agar menjadi daya untuk memperkuat kondisi pembelian saat ini.

Sementara untuk variabel yang menggunakan antara peluang dan ancaman ada diangka 2.77, dimana peluang mempunyai kontribusi nilai 2.5 yaitu unsur kenaikan permintaan pasar, segmen pasar, market share dan market growth yang meningkat, serta adanya sumber pengadaan yang diperluas, sedangkan untuk nilai ancaman sebesar 0.27 yaitu terdiri dari perusahaan sejenis diman mempunyai kelebihan dalam hal sumber pengadaan, sana, persediaan dan jaringan pasar yang luas, sehingga harus dioptimalkan terhadap peluang yang berhubungan dengan strategi pembelian agar bisa mendorong terciptanya daya saing, sehingga bisa menaikkan kinerja penjualan.

\section{Matriks SWOT}

Peneliti menganalisa SWOT ini berdasarkan pernyataan langsung dari seluruh pimpinan dan staff PT. Indo Teknik Sistem yang disesuaikan dengan kondisi real atau kenyataan yang terjadi.

Tabel D.1

ANALISA MATRIKS SWOT PT. INDO TEHNIK SISTEM

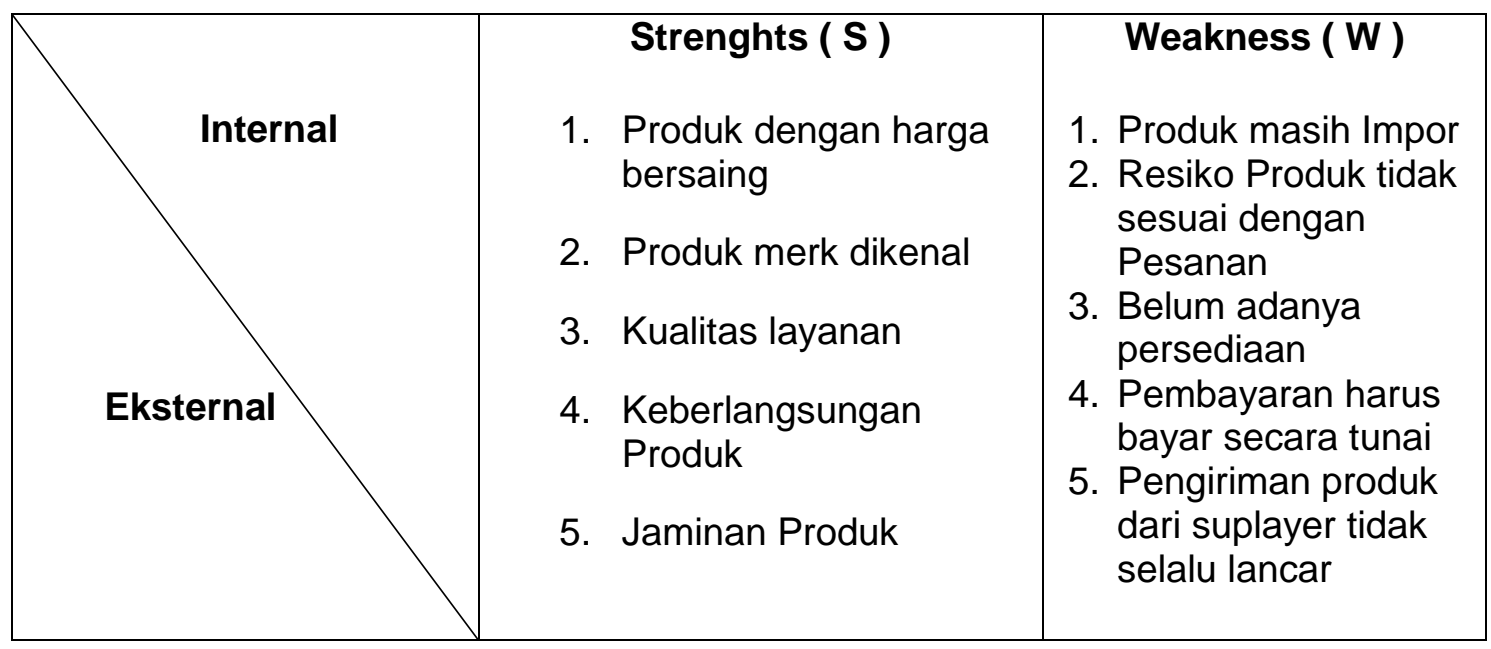




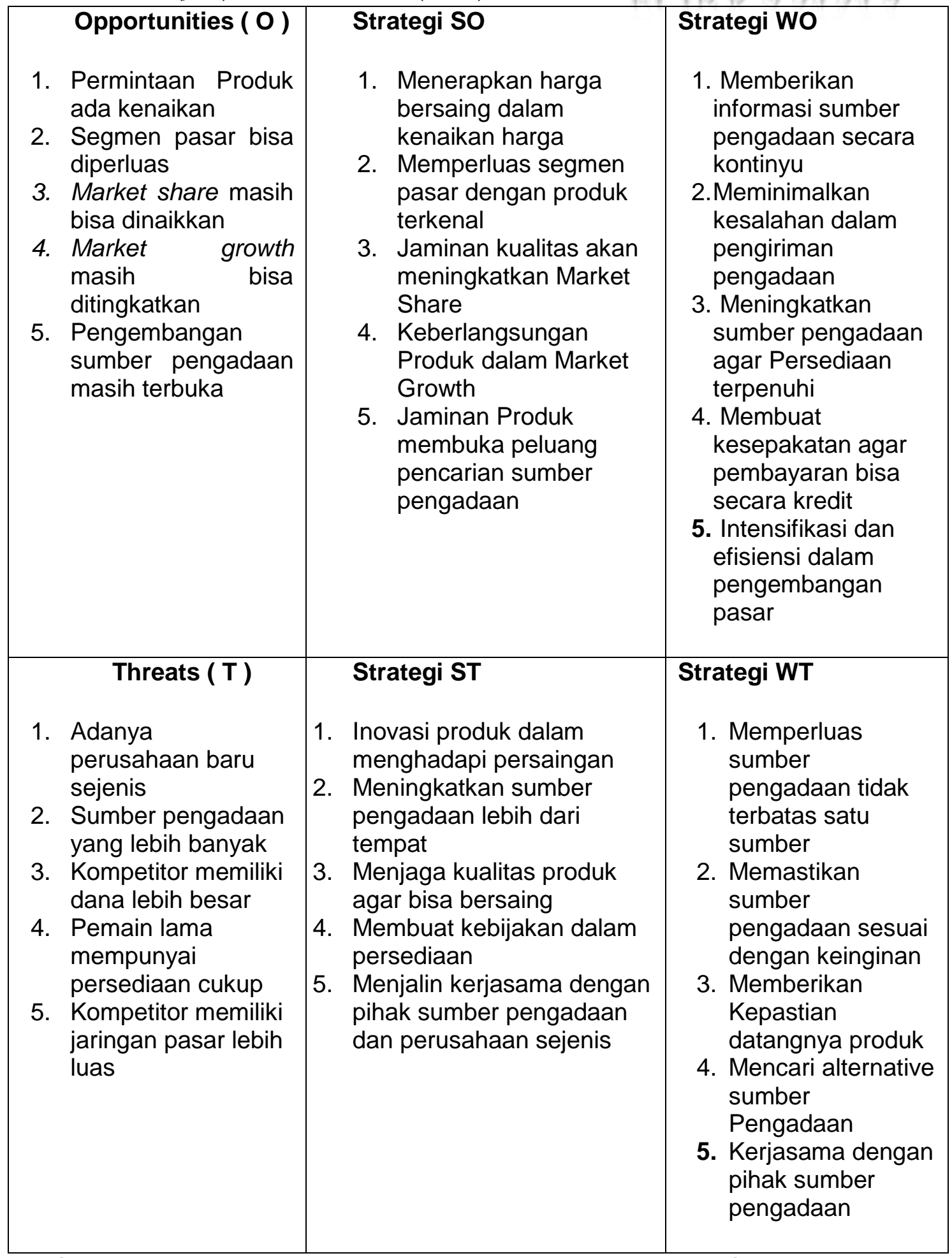

Sumber : Wawancara dengan pimpinan, staff PT Indo Tehnik Sistem

\section{Evaluasi Analisa dengan menggunakan Matriks SWOT}

Berdasarkan data hasil analisa menggunakan Matriks SWOT pada PT Indo Teknik Sistem maka :

\section{Strategi SO}

Perusahaan dalam hal ini memberikan produk dengan harga yang bersaing, dengan optimal agar permintaan terhadap produk bisa mengalami 
kenaikan, dengan memberikan harga bersaing maka akan tercipta kondisi permintaan yang semakin baik dan akan tumbuh secara maksimal. Perluasan segmen pasar menjadi penting dikarenakan yang terserap dari produk dipasar masih terbukadan bisa tumbuh dengan memperluas area perusahaan selain di perusahaan bidang pertambangan, yaitu perusahaan general industry dan manufaktur.

Kekuatan produk dengan merk yang sudah dikenal akan memudahkan dalam penentuan market share yang konsekuensinya adalah harus menjamin kualitas produk yang diadakan.Penentuan produk sangat dipengaruhi oleh adanya keberlangsungan produk yang sudah ada dan terus dijaga kualitas serta pelayanannya. Memberikan kepastian tentang jaminan produk bisa mempertimbangkan untuk sumber mencari sumber pengadaan dari lebih satu sumber atau satu Negara dengan jaminan dan kualitas yang yang hampir sama, sehingga bisa memberikan alternatif jika sumber pengadaan yang selama ini dipergunakan tidak ada dan atau ada tetapi memerlukan waktu yang lama.

\section{Strategi ST}

Mencari sumber pengadaan produk yang selalu mempunyai daya inovasi menjadi pilihan dalam mempertimbangkan agar dapat bisa bersaing dengan perusahaan yang mempunyai karakter dan kriteria yang hampir sama dalama memberikan pelayanan terhadap pengadaan produk. Alternatif mengambil sumber pengadaan dari satu tempat menjadi hal yang harus diutamakan agar tidak terjadi keterlambatan atau ketidakpastian produk bagi pelanggan.

Pengadaan produk harus mengutamakan kulitas produk, agar kepuasan pelanggan bisa terpuaskan dan bisa bersaing dengan perusahaan sejenis yang mempunyai dana lebih besar dan kuat. Melakukan terebosan dengan diadakannya persediaan dari pengadaan yang biasa oleh pelanggan yang lebih dari satu kali pembelian menjadi hal yang harus diadakan agar bisa memaksimalkan dari pengadaan untuk memberikan kepuasan pelanggan dan mengurangi biaya pengiriman.

Hal yang perlu dilakukan untuk meningkatkan daya saing dan memberikan kontribusi terhadap kinerja penjualan yang selama ini terjadi adalah dengan menjalin kerjasama dengan pihak sumber pengadaan agar lebih ditingkatkan, terutama dalam hal pembayaran tunai, bisa dinegosiasikan dengan beberapa pertimbangan sehingga bisa memberikan dampak positif bagi arus kas perusahaan sehingga, kinerja penjualan bisa ditingkatkan karena mampu mengadakan lebih banyak dari permintaan produk dari yang sebelumnya.

\section{Strategi WO}

Memberikan alternative bagi keberlangsungan perusahaan dalam hal pengadaan produk, maka diharapkan untuk mencari sumber alternative yang sesuai dengan kualitas dan pelayanan yang selama ini telah terjalin. Jika sumber pengadaan yang satu tidak sesuai dengan maka harus diusahakan untuk mendapkan sumber pengadaan yang bisa sesuai dengan yang diharapkan. Terjadinya kesalahan dalam pengiriman produk yang telah dipesan dan tidak sesuai dengan yang diinginkan oleh pelanggan menjadi tanggung jawab perusahaan demi menjaga kualitas layanan yang diberikan. Meminimalkan kesalahan dalam hal pengiriman ini, dengan menggunakan jasa pengiriman yang dipercaya dengan mengevaluasi mulai pengadaan produk keluar dari produksi sampai dengan produk tersebut terkirim kepada pelanggan.

Sumber pengadaan yang lebih dari satu diharapkan dapat memberikan dampak yang positif bagi kinerja perusahaan untuk bisa mengalokasikan anggaran dalam persedianan untuk kebutuhan produk yang diperlukan oleh 
pelanggan.

Pembayaran cash atau tunai yang selama ini dilaksanakan, dan untuk kedepannya agar bisa dibuat perjanjian dengan pihak principle dari berbagai sumber sehingga bisa dibuat kesepakatan untuk bisa diadakan pembayaran melalui skema kredit. Adanya sumber pengadaan yang lebih dari satu, dengan tempat persediaan produk dan pembayaran skema kredit bisa meningkatkan intensifikasi dan efisiensi dalam pengembangan pasar.

\section{Strategi WT}

Sumber pengadaan yang ada saat ini jika ingin bisa bersaing dengan perusahaan sejenis, maka belum bisa untuk memenuhi. Dengan membuka atau mencari sumber pengadaan baru diharapkan bisa membantu perusahaan dalam bersaing dengan perusahaan sejenis yang sudah lam mempunyai sumber pengadaan lebih dari satu sumber. Sumber pengadaan yang dicari atau direkomendasikan adalah sumber pengadaan yang memiliki kualitas produk sesuai dengan yang diinginkan pelanggan, mudah pengirimannya dan dengan sistem pembayaran yang bisa dibayar dengan skema kredit 1 atau 2 bulan kedepan.

Pengiriman dalam pencarian sumber pengadan adalah hal yang harus diperhatikan agar kepuasan pelanggan terjaga dengan kualitas produk yang sesuai.

Sumber pengadaan yang sudah lebih dari satu sumber bisa menimbulkan dampak bagi perusahaan untuk bisa menunjukkan adanya persediaan dalam perusahaan yang selama ini belum ada, sehingga diharapkan bisa mengurangi biaya yang berhubungan dengan cost produk dan bisa memberikan kontribusi bagi timbulnya kinerja penjualan.

Meningkatkan kerjasama dengan berbagai pihak dalam hal pengiriman produk dengan pihak sumber pengadaan agar tercipta efisiensidalam hal mengurangi kesalahan dalam pengiriman sehingga bisa tercipta pengiriman yang tepat waktu, sehingga tercipta kepuasan pelanggan dan bisa memperluas jangkauan pasar yang dimiliki oleh pesaing kita.

\section{F. Kesimpulan Dan Saran}

\section{Kesimpulan}

Berdasarkan hasil penelitian yang telah dilakukan oleh peneliti pada perusahaan Perdagangan Umum PT. Indo Tehnik Sistem, maka dapat ditarik kesimpulan sebagai berikut :

1. Kondisi Penjualan PT Indo Tehnik Sistem berdasar analisis IFE \& EFE dalam posisi bertahan dan menjaga.

2. Strategi yang harus dijalankan untuk meningkatkan kontribusi terhadap kenaikan kinerja penjualan adalah menerapkan strategi pembelian yang tepat dengan memberikan produk yang bersaing disaat permintaan mengalami kenaikan, dengan memberikan kepastian tentang jaminan produk dengan mempertimbangkan untuk mencari sumber pengadaan lebih dari satu tempat, dengan mempertimbangkan karakter dan kriteria dengan meminimalkan keterlambatan dan ketidakpastian pengiriman produk bagi pelanggan, sehingga tercipta kepuasan pelanggan dan bisa mendukung jangkauan pasar yang dimiliki oleh pesaing kita, yang akhirnya dapat meningkatkan kinerja penjualan. 


\section{Saran}

Berdasarkan kesimpulan diatas maka peneliti dapat memberikan beberapa saran terhadap penerapan Strategi Pembelian yang diterapkan pada PT. Indo Teknik Sistem untuk kelangsungan perusahaan kedepannya yaitu sebagai berikut

1. PT. Indo Teknik Sistem disarankan untuk agar untuk bisa mencari sumber pengadaan lebih dari satu sumber dan persediaan sehingga akan mendorong daya saing terhadap perusahaan yang sejenis yang sudah ada.

2. Meningkatkan kerjasama terhadap pihak dan bersinergi untuk mendapatkan sumber pengadaan yang lain, sehingga bisa terjamin dalam keberlangsungan dan ketepatan dalam pengiriman sehingga bisa meningkatkan kinerja penjualan.

\section{G. Daftar Pustaka}

Ferdinand, Augusty T. ( 1995 ). Manajemen Pemasaran. Hand out MM UNDIP Semarang Gautama, RR. Erlina Olivia. ( 2003 ). Analisis SWOT Sebagai Dasar Penentuan Strategi Bersaing pada PT. Windika Utama Semarang, FE UNDIP

Handoko, T. Hani ( 1999 ) . Manajemen. Yogyakarta, BPFE

Kotler, Philip. ( 1999 ). Manajemen Pemasaran : Analisis, Perencanaan, Implementasi dan Pengendalian. Jakarta, Erlangga

Indriarto, Nur dan Bambang Supomo. ( 1999 ). Metodologi Penelitian Bisnis dan Akuntansi dan Manajemen. Yogyakarta, BPFE.

Guiltinan, Joseph.P. ( 1994 ). Strategi dan Program Manajemen Pemasaran. Jakarta: Erlangga.

Jauch, Lawrence R dan William F. Glueck. ( 1999 ). Manjemen Strategis dan Kebijakan Perusahaan, Jakarta, Erlangga.

Madyasari, Rina. ( 2008 ). Analisis SWOT untuk Mengetahui posisi Perusahaan dan Implementasinya Terhadap Strategi Bersaing pada Bank Negara Indonesia ( BNI ) Syariah Kantor Cabang Semarang, FE UNDIP

Danang Sunyoto, Drs, SH, SE, MM. ( 2013 ). Perilaku Konsumen, Cetakan Pertama, CAPS, Yogyakarta.

Mudrajad Kuncoro, Ph.D, ( 2005 ). Strategi Bagaimana Meraih Keunggulan Kompetitif, Erlangga, Yogyakarta.

Sugiyono, Prof, Dr, ( 2013 ). Metode Penelitian Kuantitatif, Kualitatif dan $R \&$ D,. Edisi ke-19, Alfabeta, Bandung.

Fred R. David, ( 2010 ). Manajemen Strategis Konsep, Edisi 12, Buku 1, Salemba Empat, Jakarta

Philip Kotler, Kevin Lane Keller, ( 2008 ). Manajemen Pemasaran, Edisi ke -13, Jilid 1, Erlangga Jakarta.

Philip Kotler, Kevin Lane Keller, ( 2008 ). Manajemen Pemasaran, Edisi ke -13, Jilid 2, Erlangga Jakarta.

J. David Hunger \& Thomas C. Wheelen, ( 1996 ). Manajemen Strategis, Cetakan 16, ANDI, Yogyakarta

Sobarsa Kosasih, Dr, ME, ( 2009 ). Manajemen Operasi, Bagian Pertama, Edisi Pertama, Mitra Wacana Media, Jakarta.

Sugiyono, Prof, Dr, ( 2010 ). Metode Penelitian Bisnis, Cetakan ke - 15, Alfabeta, Bandung

Gary Dessler, ( 2011 ). Manajemen Sumber Daya Manusia, Edisi kesepuluh, Jilid 1, PT Indeks, Jakarta.

Gary Dessler, ( 2009 ). Manajemen Sumber Daya Manusia, Edisi kesepuluh, Jilid 2, PT. Indeks, Jakarta. 
Raymond McLeod, jr, George P. Schell, ( 2007 ). Sistem Informasi Manajemen, Edisi 10, Salemba Empat, Jakarta.

David Boddy, Albert Bronstra, Graham Kennedy, ( 2005 ). Managing information Systems, Second Edition, Prentice Hall, England.

Barbara C. McNurlin, Ralph H. Sparaque, Jr, ( 2006 ). Information Systems Management in Practice, Seventh Edition, New Jersey.

Burton Marcus. (1980). Modern Marketing Management, Edisi Kedua, Random House, New York.

Corl McDaniel Jr. (1979). Marketing, An Integrated Approach. Horper \& Row. Publishers, Inc, New York.

Philip Kotler, (1997). Manajemen Pemasaran : Analisis, Perencanaan, Implementasi, dan Kontrol. Edisi Revisi. Edisi bahasa Indonesia. Prentice Hall

Philip Kotler, Gary Armstrong. (1996). Dasar-dasar Pemasaran. Jilid 2.Edisi Bahasa Indonesia. Prentice Hall

Swastha Basu Drs, Irawan Drs, (1983). Manajemen Pemasaran Modern, Edisi Kedua, Liberty , Yogyakarta

William J.Stanton, (1978). Fundamentals of Marketing, Edisi kelima, Kogakhusa, Mc.Graw-Hill, Tokyo.

C.Glenn Walters, Blaise J. Bergiel ( 1989 ). Consumer Behavior : a decision - making approach, south-western Pub. Co, Univercity Michigan

Indriartoro, N dan Bambang Supomo, ( 1999 ). Metodologi Penelitian Bisnis, BPFE, Yogyakarta

Sofjan Assauri, Prof, Dr, MBA, ( 1990 ). Manajemen Pemasaran Dasar, Konsep dan Strategi, Rajawali Press, Jakarta

Soeratno dan Lincolnd Arsyad ( 2008 ). Metode Penelitian Untuk Ekonomi dan Bisnis, UPP STM YKPN, Yogyakarta

William J. Stanton, ( 2010 ). Prinsip Pemasaran, Edisi ketujuh, Erlangga Jakarta

Michael A. Hutt \& R. Diane Iselad \& Robert E. Hoslisson ( 1997, 18 ). Manajemen Strategis : Menyongsong Era Persaingan Bebas dan Globalisasi (terjemahan Armand Hediyanto ), Erlangga Jakarta

Setiwan, ( 2006 ),Pengertian Keunggulan Kompetitif, Tanggal 17 Juli 2013, Pustaka Bahan Kuliah

Alex S. Nitisemito, ( 1981 ). Marketing, Ghalia Indonesia, Jakarta

Hasyim, N. ( 2003 ), HTML ( Hypertext Markup Language) dan CSS ( Cascading Style Sheet ), http://courseware.artivisi.com di akses tanggal 10 April 2013

Soekartawi, ( 2002 ). Prinsip Dasar Manajemen Pemasaran Hasil-hasil pertanian teori dan aplikasinya, Raja Grafindo Persada, Jakarta

Hidayat, ( 1986 ). Teori Efektifitas dalam kinerja karyawan, Gajahmada Iniversity Press, Yogyakarta

Ponijan Law, Cert. Eng, Dr, Drs, MBA, MPd, ( 2010 ). Komunikasi, Gramedia, Jakarta

Gibson, RS, ( 1995 ). Principles of Nutritional Assesment, Second Edition, Oxford University Press, Newyork

Cravens, David W, ( 2000 ), Strategic Marketing $6^{\text {th }}$ edition, Irwin McGraw Hill, texas, edition, John Wiley \& Sons Inc, New York.

Day, GS and Wensley, R ( 1988 ). Assessing advantage : aframe work for diagnosing competitive superiority, Journal of Marketing, Vol. 50, pp. 1020

Fayol, Henry. 1949. General Principles of Management, dalam Shafritz, Jay M dan J. Steven Ott. 1987. Classics of Organization Theory, Brooks/Cole Publishing Company Pacific Grove, California.

Bogdan, R.C., Biklen, S.K. (1982). Qualitative Research For Education: An Introduction to Theory and Method. Boston :Allyn and Bacon, Inc.

David, 2002 : hal 26, Lembaga Ilmu Pengetahuan Indonesia, penerbit Yayasan Obor 